\title{
Interactive Multimedia Development in Social Sciences Subject of Disaster Material at Grade IV SDN. (Public Elementary School) No.024183 East Binjai on 2017/2018
}

\author{
Suwarti ${ }^{1}$, Restu $^{2}$, Hidayat ${ }^{2}$ \\ ${ }^{1}$ Master Students in State University of Medan (UNIMED), Indonesia \\ ${ }^{2}$ State University of Medan (UNIMED), Indonesia \\ Rosnidayahya@gmail.com
}

\begin{abstract}
This research deals with Interactive Multimedia Development in Social Sciences Subject of Disaster material in Grade IV SDN.(Public Elementary School) no. 024183 East Binjai on 2017/2018. As a product, interactive media is the result of solving a problem based on an audio-visual communication approach. The design of an interactive multimedia-based learning media is a visual communication design that is displayed through a monitor that can be presented at a certain time. The unavailability of learning media and the relevant learning models to be used because learning is not optimal, so the main focus of this research is the development of interactive multimedia-based learning media as an alternative in overcoming the problem of learning outcomes. This research was conducted from August 21 to November 20, 2017 in even semester at SDN (Public Elementary School) No. 024183 East Binjai having his address at Danau Laut Tawar Street, Sumber Mulyo Rejo, Binjai City, North Sumatra Province. Feasibility of using interactive multimedia on social studies subjects Disaster materials based on the results of validation from material experts and instructional media experts show that the average overall is categorized as "good" and is worthy of being used as social media learning media. The qualifications of Material experts are $82.30 \%$ with $84 \%$ percentage of guides and information, $81 \%$ multimedia material and 82.5 evaluations. The qualification of Media experts are $78 \%$ with a percentage of the assessment of each aspect namely $73 \%$ guidance and information, $82 \%$ operating software and $76 \%$ Systematic, aesthetics and media principles. Based on the results of the validation, it was concluded that the interactive multimedia of social studies subjects developed included very good criteria so that they could be accepted and used in the learning process.
\end{abstract}

Keywords: Learning media; Interactive Multimedia; Development.

\section{Introduction}

The use of learning media by utilizing educational technology is one of the solutions to developing teacher learning media. The benefits of media in learning have been felt by observers of education. this makes them keep trying to develop learning media that are relevant to the needs of students and pay attention to the pedagogical and curriculum aspects that students must achieve. Especially in line with the advances in computer technology that has many advantages. so that learning media can be integrated with technology that has improved now. In this study used interactive multimedia-based learning media.

Based on this, the development of interactive media can be useful for researchers in carrying out the stages in accordance with existing development research theories, starting from the defining, designing, development and deployment stages. As a product, interactive media is the result of solving a problem based on an audio-visual communication approach. The design of an interactive multimedia-based learning media is a visual communication design that is displayed through a monitor that can be presented at a certain time. The unavailability of learning media and relevant learning models to be used causes learning not to be optimal, so the main focus of this research is the development of interactive multimedia- 
based learning media as an alternative in overcoming the problem of learning outcomes used in learning fourth grade Social Sciences (IPS) in Elementary School 024183 East Binjai District, Binjai City.

\section{Literature Review}

\subsection{The Nature of Social Sciences Subjects}

Social studies subjects are integration subjects from the subjects of History, Geography, and Economics as well as other social science subjects (Sapriya, 2009: 7). Relation to the term Social Studies Education, according to Muhammad Numan Somantri (2001: 74): Social studies education in Indonesia is a simplification of the disciplines of social sciences and everything that is socially organized scientifically and psychologically with Pancasila and UUD 1945 as its central value to achieve educational goals (national) in particular and general national development.

This opinion is in line with what the National Council for Social Studies (NCSS) stated that: Social studies is an integrated study of social sciences and humanities to promote civic competence. Within the school program, social studies provide coordinated, systematic study of drawings on such disciplines as anthropology, archaeology, economics, geography, history, law, philosophy, political science, psychology, religion, and sociology, as well as appropriate content from the humanities, mathematics, and natural sciences. The primary purpose of social studies is to help young people develop an interdependent world of wisdom and reasoned decisions (Savage \& Armstrong, 1996: 9).

Based on this understanding, it can be seen that the characteristic of social studies is the integration or integration of various subjects (anthropology, archeology, economics, geography, history, law, philosophy, political science, psychology, religion, and sociology, humanities, mathematics, natural sciences). The main purpose of social studies is to help your generation and develop capabilities in making informed and reasoned decisions for the general good as citizens in a cultural difference, democratic society in a world that is interdependent. IPS education according to Sekar Purbarini Kawuryan (2008: 23) is: Social studies education as a subject at the elementary school level is essentially also a complete integration of the disciplines of the social sciences and other relevant scientific disciplines to realize the educational goals at the school level.

Social studies education in foreign literature is called by various terms such as Social Studies, Social Education, Citizenship Education, and Social Science Education. Limitation of IPS Education in Indonesia is an education program that chooses educational materials from the disciplines of social sciences and humanities that are organized and presented scientifically and psychologically throughout educational goals (Somantri, 2001: 79). Social studies education in Indonesia comes from the organization of social sciences and humanities. Social studies education at the school level can be interpreted as: (1) Social studies education which emphasizes the growth of values of citizenship, moral ideology of the state and religion; (2) Social studies education which emphasizes the content and methods of thinking of social scientists; (3) IPS education which emphasizes reflective inquiry; and (4) Social Studies Education which takes the goodness of items 1,2,3, above "(Somantri, 2001: 44).

Groos (Kawuryan, 2008: 24) that the main purpose of social studies is to train students to be responsible as good citizens. This is in line with what was stated by Sapriya (2009: 12) that the purpose of IPS education at the school level is to: "Preparing students as citizens who 
master knowledge, skills, attitudes and values that can be used to solve personal problems or social problems as well as the ability to take decisions and participate in various community activities in order to become citizens to the good one".

IPS ( Social science) education has the goal of forming good citizens who have knowledge, skills, attitudes and values. Social Sciences (IPS) is an integration of various branches of social sciences such as: sociology, history, geography, economics, politics, law, and culture. Social studies are formulated on the basis of reality and social phenomena which embody an interdisciplinary approach from the aspects of the branches of social sciences (sociology, history, geography, economics, politics, law, and culture). Social studies or social studies are part of the school curriculum derived from the content of the branches of social sciences: sociology, history, geography, economics, politics, anthropology, philosophy, and social psychology.

The social education program is a program that includes four dimensions including the dimensions of knowledge, dimensions of skills, dimensions of values and attitudes and dimensions of action (Sapriya, 2009: 48). Different dimensions should be included in learning activities and complementary to achieve social studies learning objectives.

\subsection{Instructional Media}

The word media comes from the Latin medius which literally means middle, intermediary or introduction. In Arabic the media is an intermediary or delivery message from the sender to the recipient of the message. Association for Education and Communication Technology (AECT) defines media as all forms used for a process of information distribution.

Learning comes from teaching words that have the meaning of a clue given to people to be known (obeyed). Then try to get intelligence or knowledge. According to Arsyad (2013: 1), learning is a complex process that occurs in a person throughout his life. In the Big Dictionary of Indonesian Language learning is a process, a way, an act of making people or living things to learn.

According to Virdayana (2011: 5), learning is an activity that contains the process of mastering knowledge, skills and attitudes by subjects who are learning. Learning is an educational aid to students to achieve maturity in the fields of knowledge, skills and attitudes. The process of learning and learning occurs because of the interaction between a person and his environment, so that it can occur anytime and anywhere. The change in a person's behavior is one sign that the person has learned and experienced the learning process. Changes in behavior can be caused by changes at the level of knowledge, skills or attitudes.

The word media is defined by multiple meanings, both limited and broad. The emergence of various definitions is caused by differences in viewpoints, intentions, and objectives. AECT (Association for Education and Communication Technology) (in Haryoso 2002) means the media as all forms used in the process of information distribution. NEA (National Education Association) means the media as all objects that can be manipulated, seen, heard, read, or discussed along with the instruments used for these activities.

Purwanto (1994) concludes some views about the media from various expert opinions, including Gagné, which places media as a component of the source, defining the media as a "component of learning resources in the environment of students who can stimulate it to learn". Briggs argues that the media must be supported by something to communicate material (curricular messages) so that the learning process occurs, Briggs defines media as a physical vehicle that contains instructional material. Schramm looks at the use of media as a technique 
for conveying messages, in which he defines media as information-carrying technology or instructional messages, whereas Miarso (2009) views media widely in the education system so that defining media is anything that can stimulate the learning process in self learners.

According to Sadiman (2003) the functions or uses of media include: (1) making concrete abstract concepts, (2) bringing dangerous or hard-to-obtain objects into the learning environment. (3) displaying objects that are too large, (4) displaying objects that cannot be observed with the naked eye, (5) observing movements that are too fast, (6) allowing students to interact directly with their environment, (7) enabling freshness of observations and perceptions for student learning observations, (8) arouse learning motivation, (9) present learning information consistently and can be repeated or stored according to need, (10) presents learning messages or information simultaneously, limits time and space constraints, and (11) controls direction and student learning speed.

In the world of education Sadiman states that media is everything that can be used to channel messages from senders to recipients so that they can stimulate students' thoughts, feelings, interests and concerns in such a way that the learning process takes place. Oemar Hamalik (2011), states that media is a tool, method, and technique used in order to make communication and interest more effective than education and education in education and learning processes in schools.

Teachers must have sufficient knowledge and understanding of learning media, namely: (1) Media as a communication tool to make the teaching and learning process more effective, (2) Function of the media in order to achieve educational goals, (3) The intricacies of learning, (4) Relationship between teaching methods and media education, (5) Value or benefits of learning media in education, (6) Selection and use of educational media, (7) Various types of educational media tools and techniques, (8) Media education in each subject, (9) Efforts to innovate in educational media. Use of learning in the learning process can generate new desires and interests, generate motivation and stimulation of learning, and even bring psychological influences to students (Arsyad, 2013: 19).

\subsection{Video Strengths and Weaknesses according to Anderson}

According to Ronald Anderson (1987: 105) video media has advantages, including:

1) By using video (accompanied by sound or not), we can show back certain movements.

2) Using certain effects can be strengthened both the learning process and the entertainment value of the presentation.

3) With videos, information can be presented simultaneously at the same time in different locations (classes) and with an unlimited number of viewers or participants by placing monitors in each class.

4) With videos students can learn independently.

\section{Research Methods}

This research was conducted from August 21 to November 20, 2017 in even semester at SDN. (Public Elementary School) No. 024183 East Binjai having his address at Danau Laut Tawar Street, Sumber Mulyo Rejo, East Binjai, Binjai City, North Sumatra Province.

\section{Discussion}


Media expert validation was carried out by Drs. Sriadhi, S.T., M. Pd., M. Kom., Ph. D, who are Postgraduate Lecturers in Medan State University. Media experts provide product validation on the aspects of guidance and information, Software Operations and Systematic, aesthetics and media principles. The results of the validation in the form of scores on the assessment of learning media in social studies subjects on aspects of the guide and information can be seen in Table 4.1.

\section{Meeting I}

Table 4.1. Scores of Learning Media Expert Assessments Guide and Information Aspects

\begin{tabular}{|c|l|c|c|c|}
\hline No & \multicolumn{1}{|c|}{ Assessment Indicator } & Score & Percentage & Criteria \\
\hline 1 & Description of multimedia products & 2 & $39 \%$ & Not Good \\
\hline 2 & Guidelines for using multimedia software & 2 & $39 \%$ & Not Good \\
\hline 3 & Help facilities & 2 & $39 \%$ & Not Good \\
\hline & Amount & 6 & & \\
\hline & Average & & $40 \%$ & Less \\
\hline
\end{tabular}

The assessment of media experts in Table 4.1 on the aspects of the guide and information obtained three items which included the "less good" category, namely a description of multimedia products, software usage guidelines and assistance facilities with learning indicators. Overall, the aspects of the guide and information are considered "not good". Validation results in the form of scores on the assessment of learning media in disaster subject matter on the operational aspects of software can be seen in Table 4.2 as follows:

Table 4.2. Media Operational Aspects of Media Expert Assessment Scores

\begin{tabular}{|c|l|c|c|c|}
\hline No & \multicolumn{1}{|c|}{ Assessment Indicator } & Score & Percentage & Criteria \\
\hline 1 & $\begin{array}{l}\text { Ease of installation and or configuration } \\
\text { settings }\end{array}$ & 4 & $80 \%$ & Good \\
\hline 2 & $\begin{array}{l}\text { The accuracy of using media navigation } \\
\text { symbols }\end{array}$ & 4 & $80 \%$ & Good \\
\hline 3 & $\begin{array}{l}\text { Ease of use of navigation buttons } \\
\text { (usability) }\end{array}$ & 4 & $80 \%$ & Good \\
\hline 4 & Search accuracy and material hyperlinks & 3 & $59 \%$ & Good Enough \\
\hline 5 & Quality of interfaces & 3 & $59 \%$ & Good Enough \\
\hline 6 & Operational consistency of software & 3 & $59 \%$ & Good Enough \\
\hline 7 & $\begin{array}{l}\text { Software operational reliability from error } \\
\text { free }\end{array}$ & 3 & $59 \%$ & Good Enough \\
\hline 8 & Operating system support required & 4 & $80 \%$ & Good \\
\hline 9 & Support for devices (hardware) needed & 4 & $80 \%$ & Good \\
\hline 10 & $\begin{array}{l}\text { Stimulus-responsive user (user) } \\
\text { interactivity with the system }\end{array}$ & 3 & $59 \%$ & Good Enough \\
\hline & \multicolumn{1}{|c|}{ Total } & 35 & & Average \\
\hline & \multicolumn{2}{|c|}{3,5} & $70 \%$ & Good \\
\hline
\end{tabular}

Tabel 4.3. Skor Penilaian Ahli Media Pembelajaran Aspek Sistematika, Estetika dan Prinsip 


\begin{tabular}{|c|c|c|c|c|}
\hline \multicolumn{5}{|c|}{ Media } \\
\hline No & Assessment Indicator & Score & Percentage & Criteria \\
\hline 1 & $\begin{array}{l}\text { Media Systematic } \\
\text { Systematic screen display }\end{array}$ & 4 & $80 \%$ & Good \\
\hline 2 & Menu facilities in the media & 4 & $80 \%$ & Good \\
\hline 3 & Letter, number and symbol acceleration & 3 & $59 \%$ & Good Enough \\
\hline 4 & $\begin{array}{l}\text { Media aesthetics } \\
\text { Visual quality (resolution) of graphics or } \\
\text { images }\end{array}$ & 4 & $80 \%$ & Good \\
\hline 5 & $\begin{array}{l}\text { Color composition and display resolution on } \\
\text { the screen }\end{array}$ & 3 & $59 \%$ & Good Enough \\
\hline 6 & Suitability of text color with background & 2 & $39 \%$ & Not Good \\
\hline 7 & $\begin{array}{l}\text { Text, visual, video and animation } \\
\text { acceleration }\end{array}$ & 3 & $59 \%$ & Good Enough \\
\hline 8 & $\begin{array}{l}\text { Quality of narration and audio } \\
\text { Narrator voice clarity }\end{array}$ & 4 & $80 \%$ & Good \\
\hline 9 & $\begin{array}{l}\text { The ease of understanding language and } \\
\text { narration }\end{array}$ & 4 & $80 \%$ & Good \\
\hline 10 & Narration is free from noise & 3 & $59 \%$ & Good Enough \\
\hline 11 & $\begin{array}{l}\text { Narrative is communicative according to user } \\
\text { needs }\end{array}$ & 4 & $80 \%$ & Good \\
\hline 12 & $\begin{array}{l}\text { Suitability of back sound with presentation } \\
\text { material }\end{array}$ & 2 & $39 \%$ & Not Good \\
\hline 13 & Setting or controlling back sound & 2 & $39 \%$ & Not Good \\
\hline 14 & Interfaced and progressive scan selection & 4 & $80 \%$ & Good \\
\hline 15 & $\begin{array}{c}\text { Video quality and or animation } \\
\text { Use of video / animation resolution (pixels) }\end{array}$ & 4 & $80 \%$ & Good \\
\hline 16 & $\begin{array}{l}\text { Suitability of video / animation objects with } \\
\text { presentation material }\end{array}$ & 5 & $100 \%$ & Very Good \\
\hline 17 & $\begin{array}{l}\text { Visualization of objects on the concepts and } \\
\text { abstract properties of matter }\end{array}$ & 4 & $80 \%$ & Good \\
\hline 18 & $\begin{array}{l}\text { The ability to reduce misperceptions of } \\
\text { objects }\end{array}$ & 3 & $59 \%$ & Good Enough \\
\hline 19 & $\begin{array}{l}\text { The principle of multimedia design } \\
\text { Application of spatial principles }\end{array}$ & 4 & $80 \%$ & Good \\
\hline 20 & Use of temporal principles & 4 & $80 \%$ & Good \\
\hline 21 & Use of clue and signaling & 3 & $59 \%$ & Good Enough \\
\hline 22 & Reducing the effect of redundancy & 3 & $59 \%$ & Good Enough \\
\hline 23 & Application of the principle of coherence & 2 & $39 \%$ & Not Good \\
\hline 24 & Use of the principle of modality & 3 & $59 \%$ & Good Enough \\
\hline 25 & Cognitive load reduction for users & 4 & $80 \%$ & Good \\
\hline & Total & 84 & & \\
\hline & Average & 3,36 & $67,2 \%$ & Good \\
\hline
\end{tabular}

Table 4.4 Level of Trends in Appraisal of Media Experts Meeting I 


\begin{tabular}{|c|l|c|c|c|}
\hline No & \multicolumn{1}{|c|}{ Assessment Indicator } & Score & Percentage & Criteria \\
\hline 1 & Guide and Information & 2 & $40 \%$ & Not Good \\
\hline 2 & Software operation & 3.5 & $70 \%$ & Good \\
\hline 3 & Systematics, aesthetics and Media Principles & 3.36 & $67.2 \%$ & Good \\
\hline \multicolumn{2}{|c|}{ Average } & 2,95 & $59 \%$ & Good Enough \\
\hline
\end{tabular}

Figure 4.1 Bar Diagram of the Percentage of Results of Assessment of Media Experts

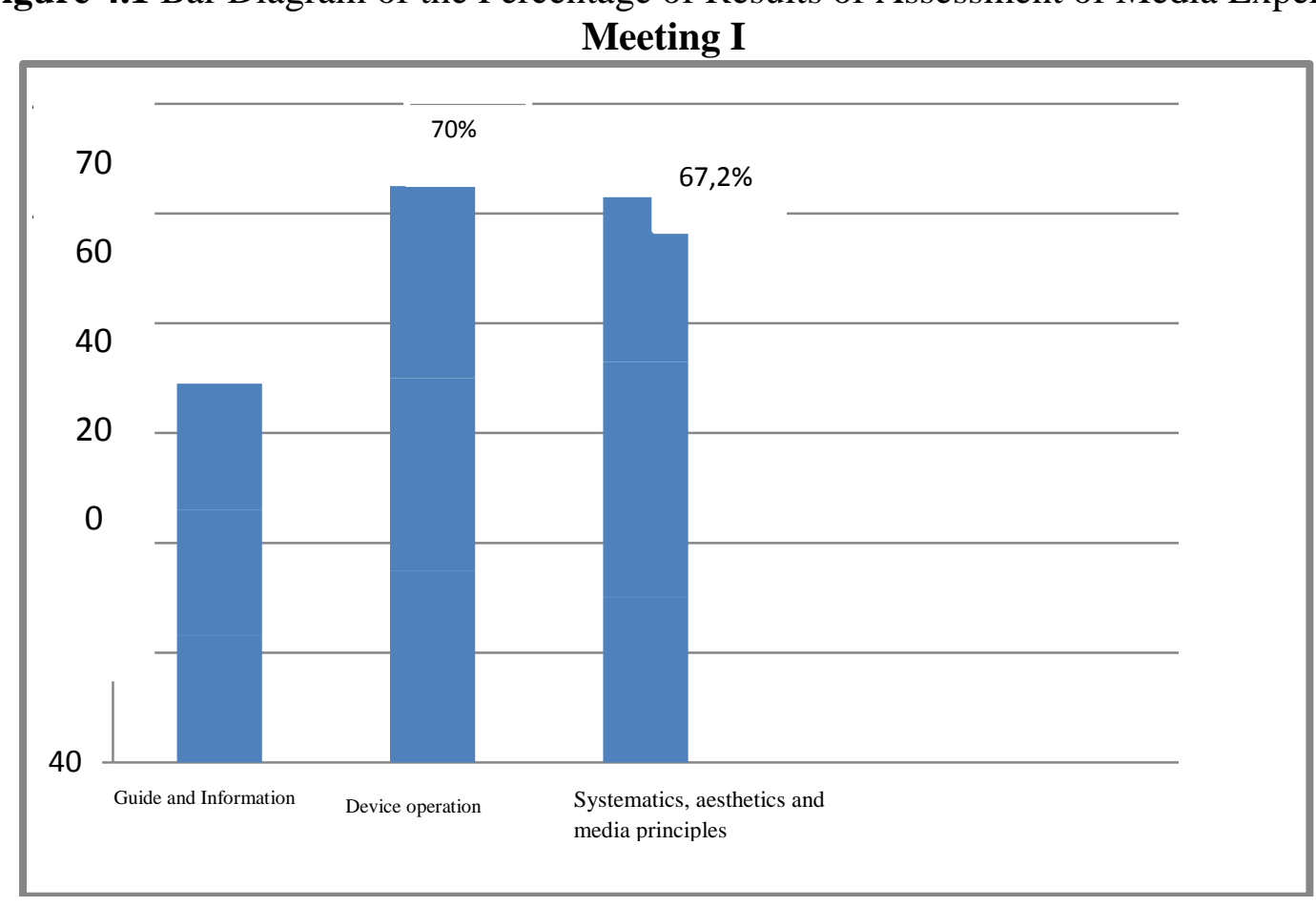

Table 4. 5. Scores for Meeting Media Expert II

\begin{tabular}{|c|l|c|c|c|}
\hline \multirow{2}{*}{ No } & \multicolumn{1}{|c|}{ Assessment Indicator } & \multirow{2}{*}{ Score } & Percentage & Criteria \\
\cline { 2 - 3 } & Guide and Information & & & \\
\hline 1 & Description of multimedia products & 4 & $80 \%$ & Good \\
\hline 2 & Guide to using multimedia software & 4 & $80 \%$ & Good \\
\hline 3 & Help facilities Total & 11 & $80 \%$ & Good \\
\hline & Average & $3,67 \%$ & $73 \%$ & Good \\
\hline
\end{tabular}

\begin{tabular}{|c|c|c|c|c|}
\hline \multirow[t]{2}{*}{ No } & Assessment Indicator & \multirow[t]{2}{*}{ Score } & \multirow[t]{2}{*}{ Percentage } & \multirow[t]{2}{*}{ Criteria } \\
\hline & Software Operations & & & \\
\hline 1 & $\begin{array}{l}\text { Ease of installation and or configuration } \\
\text { settings }\end{array}$ & 4 & $80 \%$ & Good \\
\hline 2 & $\begin{array}{l}\text { The accuracy of using media navigation } \\
\text { symbols }\end{array}$ & 4 & $80 \%$ & Good \\
\hline 3 & $\begin{array}{l}\text { Ease of use of navigation buttons } \\
\text { (usability) }\end{array}$ & 4 & $80 \%$ & Good \\
\hline 4 & Search accuracy and material hyperlinks & 4 & $80 \%$ & Good \\
\hline
\end{tabular}




\begin{tabular}{|c|l|c|c|c|}
\hline 5 & Quality of interfaces & 5 & $100 \%$ & Very Good \\
\hline 6 & Operational consistency of software & 4 & $80 \%$ & Good \\
\hline 7 & $\begin{array}{l}\text { Software operational reliability from error } \\
\text { free }\end{array}$ & 4 & $80 \%$ & Good \\
\hline 8 & Operating system support required & 4 & $80 \%$ & Good \\
\hline 9 & Support for devices (hardware) needed & 4 & $80 \%$ & Good \\
\hline 10 & $\begin{array}{l}\text { Stimulus-responsive user (user) } \\
\text { interactivity with the system }\end{array}$ & 4 & $80 \%$ & Good \\
\hline & $\quad$ Total & 41 & & Very Good \\
\hline & $\quad$ Average & 4,1 & $82 \%$ & \\
\hline
\end{tabular}

\begin{tabular}{|c|c|c|c|c|}
\hline \multirow[t]{2}{*}{ No } & Assessment Indicator & \multirow[t]{2}{*}{ Score } & \multirow[t]{2}{*}{ Percentage } & \multirow[t]{2}{*}{ Criteria } \\
\hline & $\begin{array}{l}\text { Systematic, Aesthetics and Media } \\
\text { Principles }\end{array}$ & & & \\
\hline 1 & Systematic screen display & 4 & $80 \%$ & Good \\
\hline 2 & Menu facilities in the media & 4 & $80 \%$ & Good \\
\hline 3 & Letter, number and symbol acceleration & 4 & $80 \%$ & Good \\
\hline \multirow[b]{2}{*}{4} & Media aesthetics & \multirow[t]{2}{*}{4} & \multirow[t]{2}{*}{$80 \%$} & \multirow[t]{2}{*}{ Good } \\
\hline & $\begin{array}{l}\text { Visual quality (resolution) of graphics or } \\
\text { images }\end{array}$ & & & \\
\hline 5 & $\begin{array}{l}\text { Color composition and display resolution } \\
\text { on the screen }\end{array}$ & 3 & $59 \%$ & Good Enough \\
\hline 6 & Suitability of text color with background & 3 & $59 \%$ & Good Enough \\
\hline 7 & $\begin{array}{l}\text { Text, visual, video and animation } \\
\text { acceleration }\end{array}$ & 4 & $80 \%$ & Good \\
\hline \multirow[b]{2}{*}{8} & Quality of narration and audio & \multirow[t]{2}{*}{4} & \multirow[t]{2}{*}{$80 \%$} & \multirow[t]{2}{*}{ Good } \\
\hline & Narrator voice clarity & & & \\
\hline 9 & $\begin{array}{l}\text { The ease of understanding language and } \\
\text { narration }\end{array}$ & 4 & $80 \%$ & Good \\
\hline 10 & Narration is free from noise & 4 & $80 \%$ & Good \\
\hline 11 & $\begin{array}{l}\text { Narrative is communicative according to } \\
\text { user needs }\end{array}$ & 4 & $80 \%$ & Good \\
\hline 12 & $\begin{array}{l}\text { Suitability of back sound with presentation } \\
\text { material }\end{array}$ & 3 & $59 \%$ & Good Enough \\
\hline 13 & Setting or controlling back sound & 4 & $80 \%$ & Good \\
\hline 14 & Interfaced and progressive scan selection & 4 & $80 \%$ & Good \\
\hline \multirow[b]{2}{*}{15} & Video quality and or animation & \multirow[t]{2}{*}{5} & \multirow[t]{2}{*}{$100 \%$} & \multirow[t]{2}{*}{ Very Good } \\
\hline & Use of video / animation resolution (pixels) & & & \\
\hline 16 & $\begin{array}{l}\text { Suitability of video / animation objects } \\
\text { with presentation material }\end{array}$ & 4 & $80 \%$ & Good \\
\hline 17 & $\begin{array}{l}\text { Visualization of objects on the concepts } \\
\text { and abstract properties of matter }\end{array}$ & 4 & $80 \%$ & Good \\
\hline 18 & The ability to reduce misperceptions of & 4 & $80 \%$ & Good \\
\hline
\end{tabular}




\begin{tabular}{|c|c|c|c|c|}
\hline & objects & & & \\
\hline \multirow[b]{2}{*}{19} & The principle of multimedia design & \multirow[t]{2}{*}{4} & \multirow[t]{2}{*}{$80 \%$} & \multirow[t]{2}{*}{ Good } \\
\hline & Application of spatial principles & & & \\
\hline 20 & Use of temporal principles & 4 & $80 \%$ & Good \\
\hline 21 & Use of clue and signaling & 4 & $80 \%$ & Good \\
\hline 22 & Reducing the effect of redundancy & 4 & $80 \%$ & Good \\
\hline 23 & Application of the principle of coherence & 5 & $100 \%$ & Very Good \\
\hline 24 & Use of the principle of modality & 4 & $80 \%$ & Good \\
\hline \multirow[t]{3}{*}{25} & Cognitive load reduction for users & 4 & $80 \%$ & Good \\
\hline & Total & 95 & & \\
\hline & Average & 3,8 & $76 \%$ & Good \\
\hline
\end{tabular}

Based on the assessment of media experts, the interactive multimedia products in social studies subject matter of Disaster developed in good qualifications (78\%) so that the learning media is not revised again and is suitable for use.

Table 4.6. Level of Trends in Assessment of Media Experts Meeting II

\begin{tabular}{|c|l|c|l|c|}
\hline No & \multicolumn{1}{|c|}{ Assessment Indicator } & Score & Percentage & Criteria \\
\hline 1 & Guide and Information & 3,67 & $73 \%$ & Good \\
\hline 2 & Software operations & 4,1 & $82 \%$ & Very Good \\
\hline 3 & $\begin{array}{l}\text { Systematics, aesthetics and Media } \\
\text { Principles }\end{array}$ & 3,8 & $76 \%$ & Good \\
\hline \multicolumn{1}{|c|}{ Total } & $\mathbf{1 1 , 5 7}$ & & $\mathbf{7 7 \%}$ & Good \\
\hline & \multicolumn{2}{|c|}{ Average } & $\mathbf{3 , 8 5}$ & \multicolumn{2}{c}{} \\
\hline
\end{tabular}

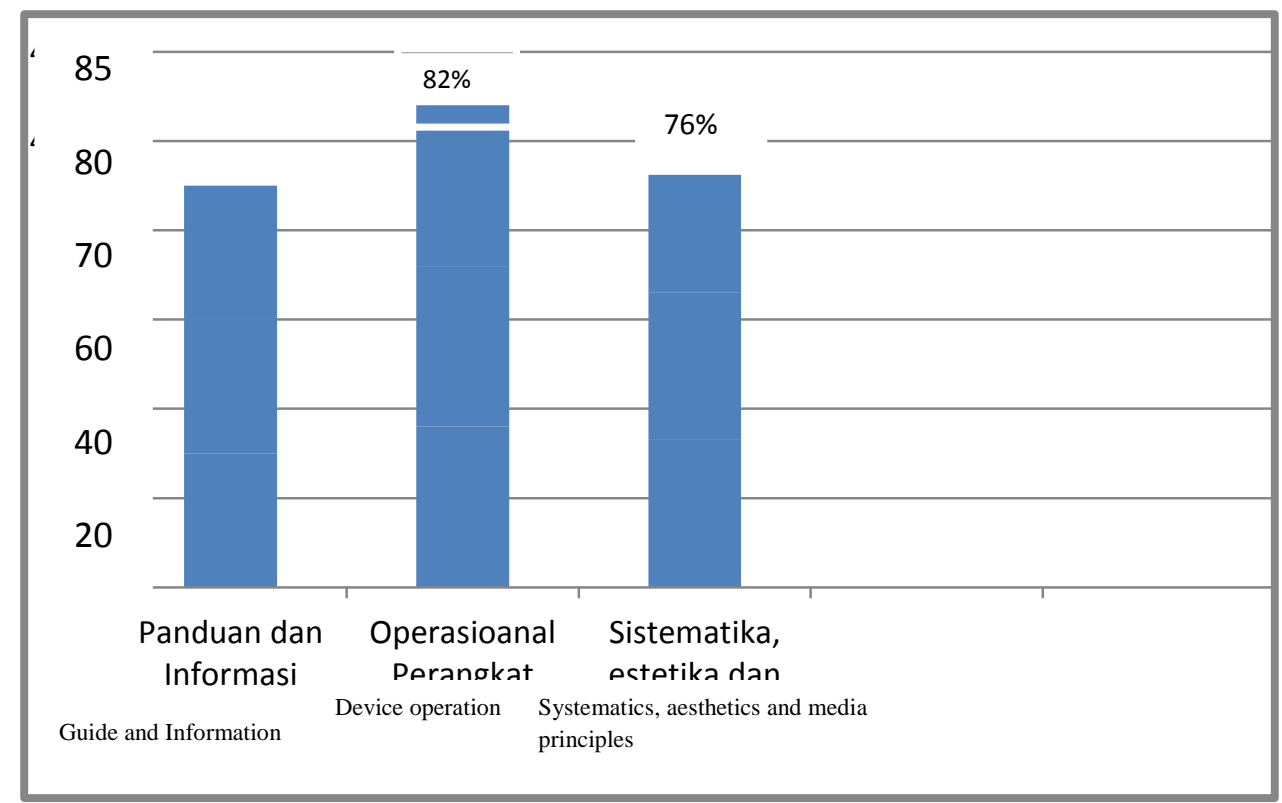

Figure 4.2. Bar Diagram of Percentage of Evaluation Results of Media Experts 
Budapest International Research and Critics in Linguistics and Education (BirLE) Journal

Volume 2, No 1, February 2019, Page: 216-232

e-ISSN: 2655-1470 (Online), p-ISSN: 2655-2647 (Print)

www.bircu-journal.com/index.php/birle

emails: birle.journal@gmail.com

birle.journal.qa@gmail.com

\section{Meeting II}

The assessment of each of the three aspects shows the percentage of each assessment which is $73 \%$ on the aspect of guidance and information, $82 \%$ on the operational aspects of the software, $76 \%$ on the systematic, aesthetic and media principles. Based on these assessments as a whole interactive multimedia on social studies subjects in disaster material in the category "Good".

Validation results from media experts were analyzed as a basis for revisions to improve learning media. Overall the conclusion of the validator on the interactive multimedia assessment produced was declared "good" and did not need improvement.

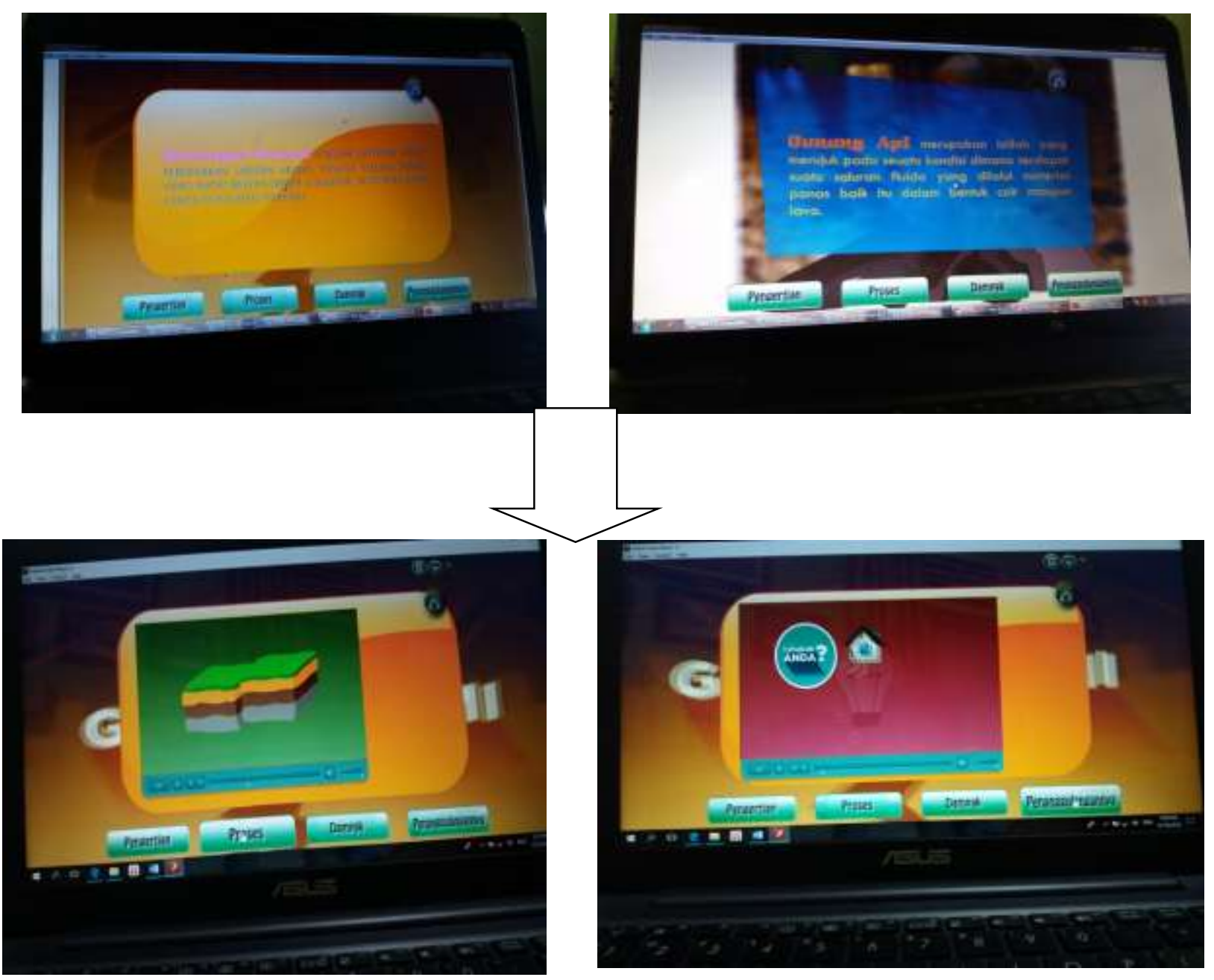

Figure 4.3. Interactive Multimedia Display Before and after Product Revision

Individual trials conducted at SDN.024183 East Binjai aimed at identifying product shortcomings after being reviewed by experts on the presentation of learning products covering the aspects of the quality of learning material and aspects of technical quality. Individual trials were conducted on 3 odd semester students consisting of 1 high achiever student, 1 moderate achievement student and 1 low achieving student. The results of the trial 
in the form of an assessment score on learning media in individual trials can be seen in Table 4.18 as follows:

Table 4.7. Individual Trial Assessment Scores about Aspects of Learning Material Quality

\begin{tabular}{|c|c|c|c|c|c|c|c|c|}
\hline \multirow[t]{2}{*}{ No } & \multirow[t]{2}{*}{ Assessment Indicator } & \multicolumn{4}{|c|}{ Responden } & \multirow[t]{2}{*}{ Total Score } & \multirow[t]{2}{*}{ Percentage } & \multirow[t]{2}{*}{ Criteria } \\
\hline & & 1 & 2 & 3 & 4 & & & \\
\hline 1 & Material compatibility & 4 & 4 & 4 & 4 & 12 & $70,00 \%$ & Good \\
\hline 2 & $\begin{array}{l}\text { Clarity of learning } \\
\text { instructions }\end{array}$ & 5 & 5 & 5 & 5 & 15 & $100,00 \%$ & Very Good \\
\hline 3 & $\begin{array}{l}\text { Ease of understanding } \\
\text { learning }\end{array}$ & 5 & 5 & 4 & 5 & 14 & $93,33 \%$ & Very Good \\
\hline 4 & $\begin{array}{l}\text { The accuracy of the } \\
\text { order of presentation }\end{array}$ & 3 & 4 & 4 & 3 & 11 & $73,00 \%$ & Good \\
\hline 5 & Adequacy of training & 4 & 4 & 4 & 4 & 12 & $80,00 \%$ & Good \\
\hline 6 & Feedback clarity & 4 & 5 & 5 & 4 & 14 & $93,33 \%$ & Very Good \\
\hline 7 & $\begin{array}{l}\text { Help learning with the } \\
\text { program }\end{array}$ & 5 & 5 & 5 & 5 & 15 & $100,00 \%$ & Very Good \\
\hline & Total & & & & & 93 & & \\
\hline & Average & & & & & 13,28 & 88,57 & Very Good \\
\hline
\end{tabular}

Table 4.19 shows the responses of 3 students in individual trials at SDN. 024183 Binjai Timur Interactive Multimedia IPS subject matter Disaster from the aspect of the quality of learning material and as a whole is stated in the criteria of "very good" with the percentage $(88.57 \%)$. Student assessment on interactive learning media about technical quality / display can be seen in Table 4.20 as follows:

Table 4.8. Individual Test Assessment Scores about Aspects of Technical / Display Quality

\begin{tabular}{|c|c|c|c|c|c|c|c|}
\hline \multirow[t]{2}{*}{ No } & \multirow[t]{2}{*}{ Assessment Indicator } & \multicolumn{3}{|c|}{ Responden } & \multirow[t]{2}{*}{ Total Score } & \multirow[t]{2}{*}{ Percentage } & \multirow[t]{2}{*}{ Criteria } \\
\hline & & 1 & 2 & 3 & & & \\
\hline 1 & Display Beauty & 5 & 4 & 4 & 13 & $70,00 \%$ & Good \\
\hline 2 & Text readability & 5 & 4 & 5 & 14 & $100,00 \%$ & Very Good \\
\hline 3 & $\begin{array}{l}\text { Image quality and } \\
\text { animation }\end{array}$ & 5 & 5 & 4 & 14 & $93,33 \%$ & Very Good \\
\hline 4 & Color composition & 5 & 4 & 4 & 13 & $73,00 \%$ & Good \\
\hline 5 & Navigation & 5 & 4 & 4 & 13 & $80,00 \%$ & Good \\
\hline 6 & Music support & 4 & 5 & 5 & 14 & $93,33 \%$ & Very Good \\
\hline 7 & Interaction & 4 & 4 & 5 & 13 & $100,00 \%$ & Very Good \\
\hline & Total & & & & 94 & & \\
\hline & Average & & & & 13,42 & 89,52 & Very Good \\
\hline
\end{tabular}

Student's response to individual tests at SDN. 024183 East Binjai shown in Table 4.20 explained that IPS interactive multimedia learning media from the aspect of technical quality or the appearance of the majority were assessed as being overall considered "very good" with a percentage of $89.52 \%$. The results of the assessment on individual trials on aspects of the quality of learning materials for interactive multimedia learning media for social studies subjects in disaster material are summarized in Table 4.21 as follows: 
Table 4.9. Level of Trends in Assessment of Learning Media Interactive Multimedia Individual Trial

\begin{tabular}{|l|l|l|l|}
\hline No & Aspect & Score of Average & Criteria \\
\hline 1 & Quality of learning material & $88,57 \%$ & Very Good \\
\hline 2 & Display technical quality & $89,52 \%$ & Very Good \\
\hline & Average & $\mathbf{8 9 , 0 4 \%}$ & Very Good \\
\hline
\end{tabular}

The average percentage of the results of individual trials on aspects of the quality of disaster learning material in class IV SDN. 024183 East Binjai seen in Figure 4.9 as follows:

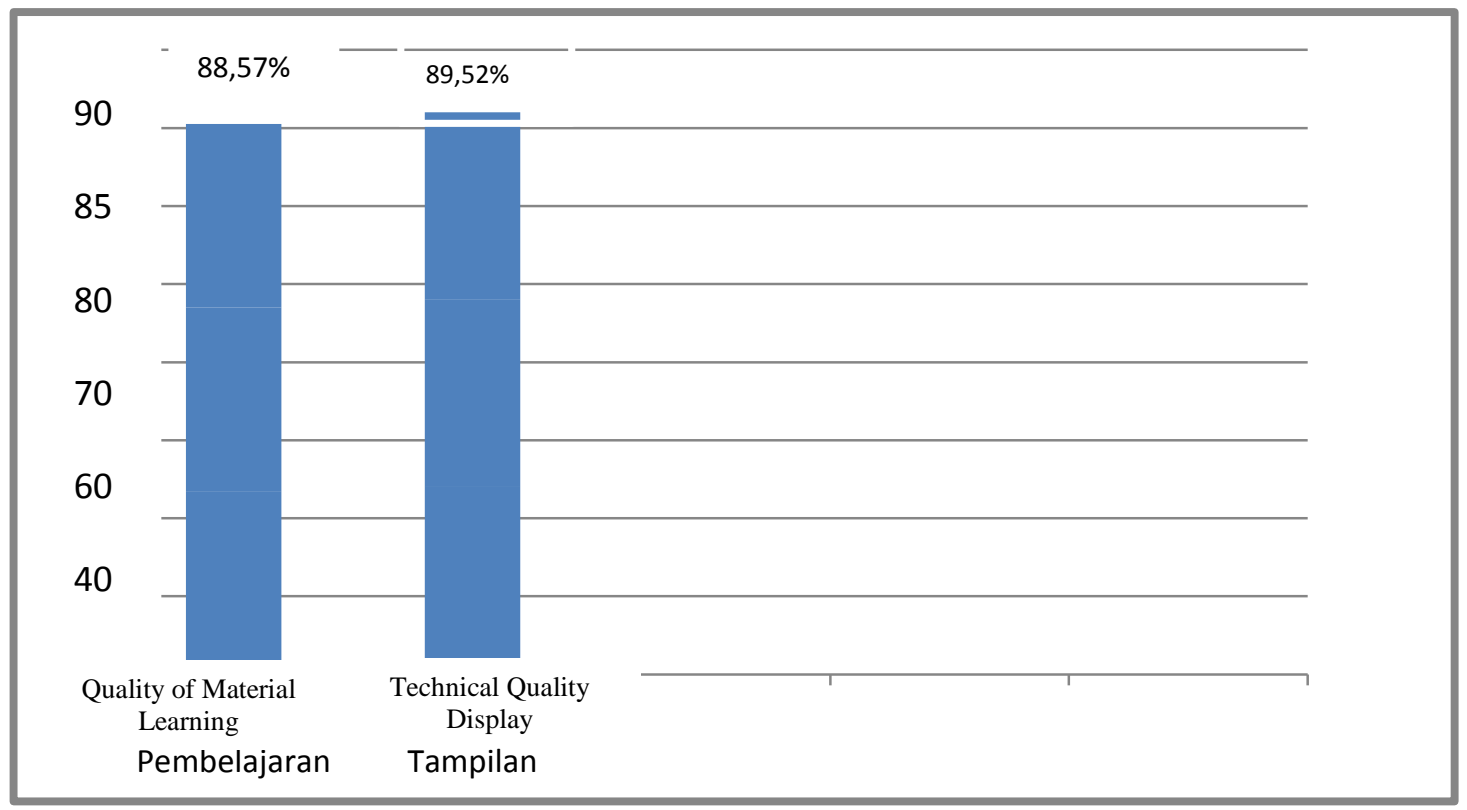

Figure 4.4. Bar Diagram Acquiring Scores of Interactive Learning Media for Social Studies Individual Test Subjects

Small group trials were also conducted at SDN.024183 East Binjai. Small group trials were conducted on 9 students consisting of 3 high achieving students, 3 moderate achievers, and 3 low achieving students. The small group trial data is intended to find out some of the weaknesses or obstacles faced when interactive multimedia learning media products are used. This small group trial is used as an initial experience before the product is piloted into the field. The results of evaluation on the quality aspects of learning materials can be seen Table 4.22 as follows:

Table 4.10. Small Group Trial Assessment Scores About Aspects of Quality of learning material

\begin{tabular}{|c|l|c|c|c|c|c|l|c|}
\hline \multirow{2}{*}{ No } & Assessment Indicator & \multicolumn{5}{|c|}{ Score } & Percentage & Criteria \\
\cline { 3 - 7 } & & $\mathbf{1}$ & $\mathbf{2}$ & $\mathbf{3}$ & $\mathbf{4}$ & $\mathbf{5}$ & & \\
\hline 1 & Material compatibility & & & & 3 & 6 & $86,67 \%$ & Very Good \\
\hline 2 & $\begin{array}{l}\text { Clarity of learning } \\
\text { instructions }\end{array}$ & & & & 5 & 4 & $88,89 \%$ & Very Good \\
\hline 3 & Ease of understanding & & & & 3 & 6 & $93,33 \%$ & Very Good \\
\hline
\end{tabular}




\begin{tabular}{|c|l|l|l|l|l|l|l|l|}
\hline & learning & & & & & & & Very Good \\
\hline 4 & $\begin{array}{l}\text { The accuracy of the order of } \\
\text { presentation }\end{array}$ & & & & 4 & 5 & $91,11 \%$ & Very Good \\
\hline 5 & Adequacy of training & & & & 4 & 5 & $91,11 \%$ & Very Good \\
\hline 6 & Feedback clarity & & & & 3 & 6 & $93,33 \%$ & Very Good \\
\hline 7 & $\begin{array}{l}\text { Help learning with the } \\
\text { program }\end{array}$ & & & & 2 & 7 & $95,56 \%$ & \\
\hline & \multicolumn{1}{|c|}{ Average } & & & & & & $\mathbf{9 1 , 4 2 \%}$ & \\
\hline
\end{tabular}

Assessment of the quality aspects of the learning material for a small group trial at SDN.024183 East Binjai which appears 4.21. Shows that overall the criteria are "very good" with a percentage of $91.42 \%$. The results of the evaluation of interactive multimedia learning media in social studies subject matter of Disaster on aspects of technical quality or appearance can be seen in Table 4.23.

Table 4.11. Scores of Assessment of Interactive IPS Learning Media Trial Small Groups on Technical or Display Quality Aspects

\begin{tabular}{|c|l|c|c|c|c|c|l|c|}
\hline \multirow{2}{*}{ No } & Assessment Indicator & \multicolumn{5}{|c|}{ Score } & \multirow{2}{*}{ Percentage } & Criteria \\
\cline { 4 - 7 } & & $\mathbf{1}$ & $\mathbf{2}$ & $\mathbf{3}$ & $\mathbf{4}$ & $\mathbf{5}$ & & \\
\hline 1 & Display Beauty & & & & 4 & 5 & $91,11 \%$ & Very Good \\
\hline 2 & Text readability & & & & 3 & 6 & $93,33 \%$ & Very Good \\
\hline 3 & Image quality and animation & & & & 4 & 5 & $91,11 \%$ & Very Good \\
\hline 4 & Color composition & & & & 4 & 5 & $91,11 \%$ & Very Good \\
\hline 5 & Navigation & & & & 6 & 3 & $93,33 \%$ & Very Good \\
\hline 6 & Music support & & & & 5 & 4 & $88,89 \%$ & Very Good \\
\hline 7 & Interaction & & & & 2 & 7 & $95,55 \%$ & Very Good \\
\hline & \multicolumn{2}{|c}{ Average } & & & & & $\mathbf{9 2 , 0 6 \%}$ & Very Good \\
\hline
\end{tabular}

Table 4.12. Level of Trends in Assessment of Learning Media Small Group Interactive Multimedia Trial

\begin{tabular}{|c|l|l|c|}
\hline No & \multicolumn{1}{|c|}{ Aspects } & Average & Criteria \\
\hline 1 & Quality of learning material & $91,42 \%$ & Very Good \\
\hline 2 & Display technical quality & $92,06 \%$ & Very Good \\
\hline & Average & $91,74 \%$ & Very Good \\
\hline
\end{tabular}

The average percentage of the results of small group trials on aspects of the quality of disaster learning material in class IV SDN. 024183 East Binjai seen in Figure 4.10 as follows: 


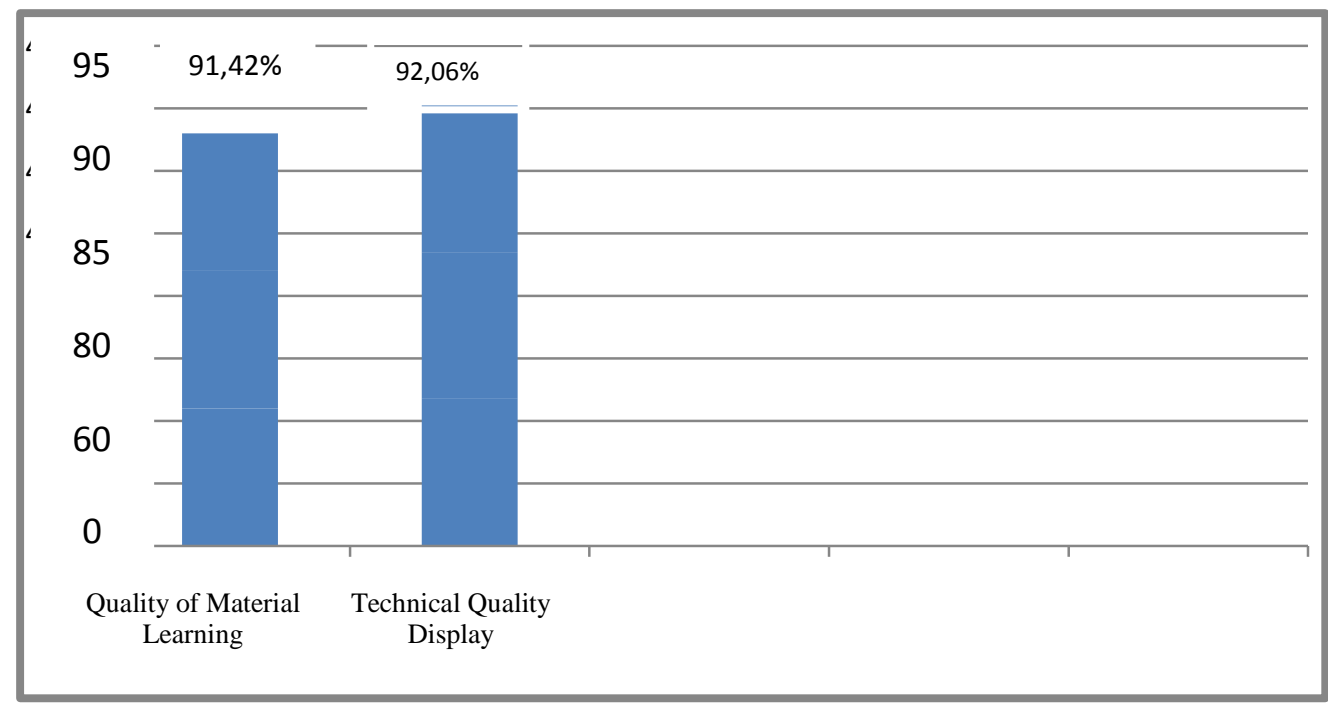

Figure 4.5 Bar Diagram of the Score of Multimedia Learning Media Interactive IPS Test Subjects

\section{Small Group}

In the small group trial activities carried out on 9 students seen in Figure 4.10. shows the results of the responses of fourth grade students of SDN.024183 East Binjai conducted on aspects of material quality and the quality of display techniques that show that interactive multimedia learning media for social studies subjects Material Disaster is stated in the criteria of "Very Good". In a small group trial conducted on 9 students of grade IV SDN. 024183 East Binjai has not been repaired.

Field trials were conducted on fourth grade students of SDN.024183 East Binjai consisting of 30 students. Field trials produce data that will later measure the feasibility of the product being developed, and to find out how the product benefits the user. The results of the evaluation of learning media on aspects of the quality of learning materials can be seen in table 4.25.

Table 4.13. Field Trial Assessment Scores on Aspects of Quality of learning material

\begin{tabular}{|c|l|c|c|c|c|c|c|c|}
\hline \multirow{2}{*}{ No } & \multicolumn{1}{|c|}{ Assessment Indicator } & \multicolumn{5}{|c|}{ Score } & \multirow{2}{*}{ Percentage } & Criteria \\
\cline { 3 - 7 } & & $\mathbf{1}$ & $\mathbf{2}$ & $\mathbf{3}$ & $\mathbf{4}$ & $\mathbf{5}$ & & \\
\hline 1 & Material compatibility & & & & 9 & 21 & $94,67 \%$ & Very Good \\
\hline 2 & Clarity of learning instructions & & & & 4 & 26 & $97,33 \%$ & Very Good \\
\hline 3 & $\begin{array}{l}\text { Ease of understanding } \\
\text { learning }\end{array}$ & & & 9 & 21 & $94,00 \%$ & Very Good \\
\hline 4 & $\begin{array}{l}\text { The accuracy of the order of } \\
\text { presentation }\end{array}$ & & & & 9 & 21 & $94,00 \%$ & Very Good \\
\hline 5 & Adequacy of training & & & & 3 & 27 & $98,00 \%$ & Very Good \\
\hline 6 & Feedback clarity & & & & 3 & 27 & $98,00 \%$ & Very Good \\
\hline 7 & $\begin{array}{l}\text { Help learning with the } \\
\text { program }\end{array}$ & & & & 9 & 21 & $94,00 \%$ & Very Good \\
\hline & \multicolumn{1}{|c|}{ Average } & & & & & & $\mathbf{9 5 , 1 4 \%}$ & \\
\hline
\end{tabular}

Table 4.25 shows the results of student responses to the quality aspects of the learning material for the overall field trial in the criteria of "very good" with a percentage of $95.14 \%$. 
The results of student responses to aspects of technical quality or appearance for field trials in class IV SDN.024183 East Binjai can be seen in table 4.26 as follows:

Table 4.14. Field Trial Assessment Scores on Technical or Display Quality Aspects

\begin{tabular}{|c|c|c|c|c|c|c|c|c|}
\hline \multirow[t]{2}{*}{ No } & \multirow[t]{2}{*}{ Assessment Indicator } & \multicolumn{5}{|c|}{ Score } & \multirow[t]{2}{*}{ Percentage } & \multirow[t]{2}{*}{ Criteria } \\
\hline & & 1 & 2 & 3 & 4 & 5 & & \\
\hline 1 & Display Beauty & & & & 4 & 26 & $97,33 \%$ & Very Good \\
\hline 2 & Text readability & & & & 7 & 23 & $95,33 \%$ & Very Good \\
\hline 3 & Image quality and animation & & & & 7 & 23 & $95,33 \%$ & Very Good \\
\hline 4 & Color composition & & & & 12 & 18 & $92,00 \%$ & Very Good \\
\hline 5 & Navigation & & & & 9 & 21 & $94,00 \%$ & Very Good \\
\hline 6 & Music support & & & & 9 & 21 & $94,00 \%$ & Very Good \\
\hline 7 & Interaction & & & & 6 & 24 & $96,67 \%$ & Very Good \\
\hline & Average & & & & & & $94,95 \%$ & Very Good \\
\hline
\end{tabular}

Table 4.15. Level of Trends in Assessment of Field Trials

\begin{tabular}{|c|l|l|c|}
\hline No & \multicolumn{1}{|c|}{ Aspects } & Average & Criteria \\
\hline 1 & Quality of learning material & $95,14 \%$ & Very Good \\
\hline 2 & Display technical quality & $94,95 \%$ & Very Good \\
\hline & Average & $\mathbf{9 5 , 0 4 \%}$ & Very Good \\
\hline
\end{tabular}

The average percentage from the results of field trials is shown in Figure 4.11 as follows:

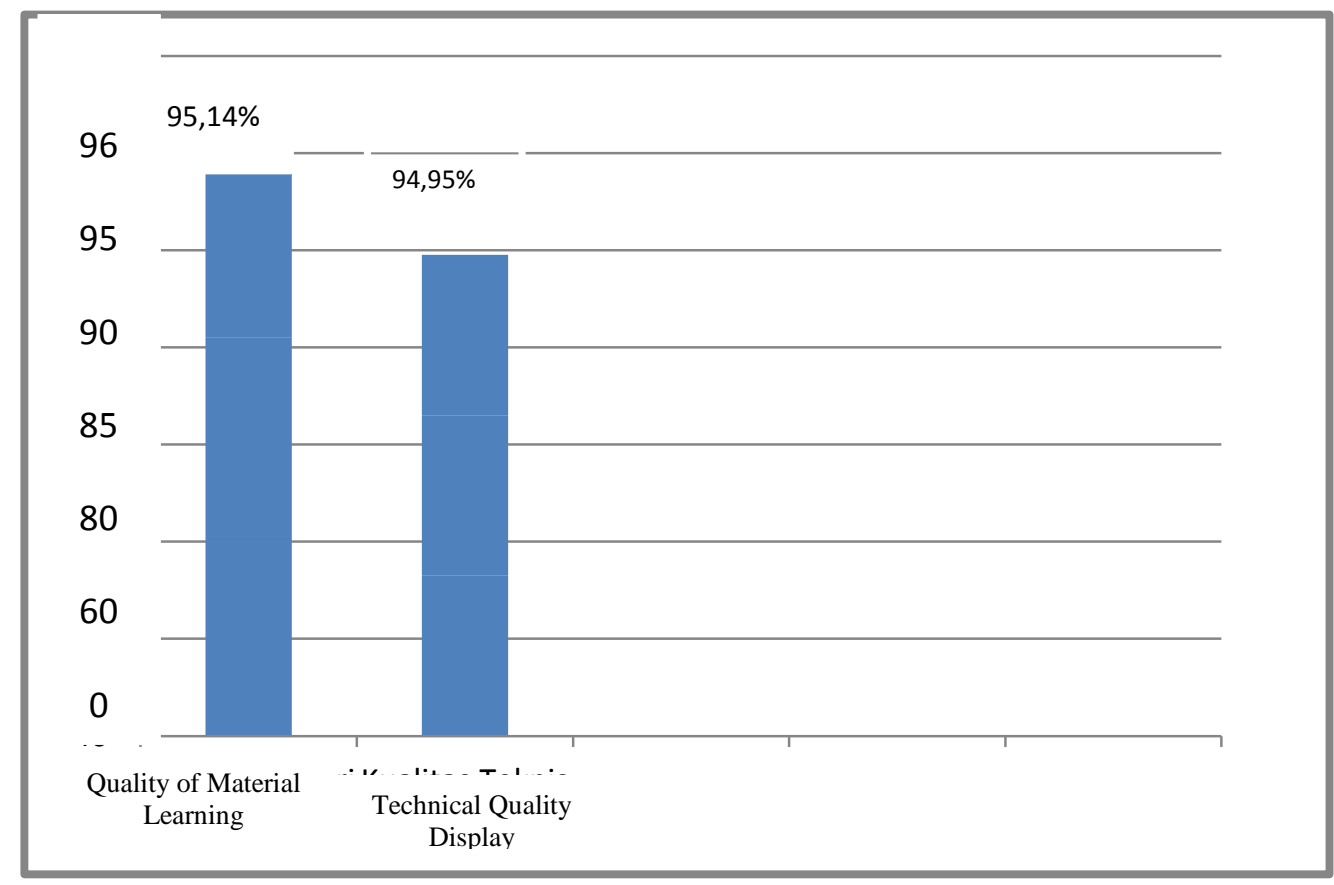

Figure 4.6 Bar Diagram of Obtaining Field Trial Scores

In the field trial activities carried out 30 students were seen in the picture showing the results of student responses at SDN. 024183 East Binjai conducted on aspects of the quality of 
learning material and the technical quality of the display which shows that interactive multimedia learning media for social studies subjects in disaster material are stated in the criteria of "Very Good" with an average percentage of 95.04. In field trials conducted on 30 students at SDN. 024183, there are no suggested improvements. In general students stated that the learning media developed was very good. Thus there is no revision at the field trial stage, which also means interactive multimedia learning media for social studies subject matter that is developed is very good or feasible to use and ready to be tested for its effectiveness.

\section{Conclusion}

Feasibility of using interactive multimedia on social studies subjects Disaster materials based on the results of validation from material experts and instructional media experts show that the average overall is categorized as "good" and is worthy of being used as social media learning media. The qualifications of Material experts are $82.30 \%$ with $84 \%$ percentage of guides and information, $81 \%$ multimedia material and 82.5 evaluations. The qualification of Media experts are $78 \%$ with a percentage of the assessment of each aspect namely $73 \%$ guidance and information, $82 \%$ operating software and $76 \%$ Systematic, aesthetics and media principles. Based on the results of the validation, it was concluded that the interactive multimedia of social studies subjects developed included very good criteria so that they could be accepted and used in the learning process.

\section{References}

Agus Suheri. 2006. "Animasi Multimedia Pembelajaran" Jakarta : Elec media Komputindo.

Anderson, Ronad. H. 1987, Pemilihan dan Pengembangan Media untuk Pembelajaran, Jakarta: Rajawali Pers, Team Penerjemah Yusuf Hadi Miarso at el.

Azhar Arsyad. 2013. Media Pembelajaran. Jakarta :Raja grafindo Persada.

Borg, Walter R. \& Gall, Meredith D. 2003 .Educational Research.New York : Longman

Daryanto. 2010. Evaluasi Pendidikan. Jakarta: Rineka Cipta.

Depdiknas. 2008. Panduan Pengembangan Bahan Ajar. Jakarta: Direktorat Pembinaan SMA, Dirjen Mandikdasmen, Depdiknas.

Feny Mega Vistha, 2010. Pengembangan Media Pembelajaran Geometri Ruang Berbasis Multimedia Pada Materi Bangun Ruang Sisi Datar Untuk Siswa SMP Kelas VIII, Universitas Negeri Yogyakarta

Gagne, at el. 2005.Principles of instructional design ( $5^{\text {th }}$ ed.). Belmont, CA: Thomson/ Wadsworth.

Gunawan, Rudy. 2011. Tujuan Pembelajaran IPS Sekolah Dasar.dalam http://www.rudygunawan.blogspot.com Internet accessed on 23 March 2014.

Heinich, R. dkk. 1996. Instructional media am technologies for learning. Englewood Cliffs. New Jersey: A Simon and Schuster Company.

Hamalik, Oemar. 2011. Kurikulum dan Pembelajaran. Jakarta: Bumi Aksara.

Hofstetter, Fred.T. 2001. Multimedia Literacy Third Edition MC.Graw-Hill International Edition New York

Joyce, Bruce and Weil, Marsha. 1980. Models of Teaching (Second Edition). Englewood Cliffs, New Jersey: Prentice-Hall, Inc 
Jurnal Teknologi Informasi \& Komunikasi dalam Pendidikan, Vol. 1.No. 2, Dec. 2014, pISSN: 2355-4983 ; e-ISSN: 2407-7437, Intan Permata Putri, Pengembangan Media Interaktif Pada Mata Pelajaran Fisika, MTsN 3 Medan, PPs Universitas Negeri Medan

Jurnal Teknologi Pendidikan, Vol 5. No.1 April. 2012, p- ISSN 1979 - 6692, Lingin, Pengembangan Media Pembelajaran Interaktif Pada Mata Pelajaran Geografi , Teknik Elektro FT,PPs Universitas Negeri Medan

Jurnal Teknologi Informasi \& Komunikasi dalam Pendidikan, Vol. 1, No. 1, Juni 2014, pISSN: 2355-4983; e-ISSN: 2407-7488, Hendra, Penggunaan Media Pembelajaran Interaktif dan Komunikasi Interpersonal Terhadap Hasil Belajar Kimia SMA Swasta Sutomo 2 Medan PPs Universitas Negeri Medan

Januszewski, A., Molenda, M. 2008. Educational Technology. New York: Lawrence Erlbaum Associates.

Miarso, Y, H. 2004. Menyemai Benih Teknologi Pendidikan. Jakarta: Kencana

Muhammad Numan Somantri. 2001. Menggagas Pembaharuan Pendidikan IPS. Bandung :Remaja Rosdakarya.

Mulyatiningsih, Endang. 2012. Metode Penelitian Terapan di Bidang Pendidikan.Bandung :Alfabeta.

Rusman. 2013. Belajar dan Pembelajaran Berbasis Komputer (Mengembangkan Profesionalisme Abad 21). Bandung :Alfabeta.

Sanjaya, Wina. 2013. PenelitianPendidikan. Jakarta: Kencana.

Sapriya. 2009. Pendidikan IPS. Bandung : PT. Remaja Rosdakarya.

Sekar Purbarini Kawuryan. 2008. Pentingnya Pendidikan IPS di Sekolah Dasar sebagai Kerangka Dasar Nation and Character Building. Dinamika Pendidikan.

Smaldino E. Sharon, 2008. Instructional Technology and Media for Learning.Jakarta :KencanaPrenada Media Group.

Soemantri. 2004. Proses Pembelajaran IPS Sekolah Dasar. In http://www.pembelajaransoemantri.wordpress.com/ Internet accessed on 22 March 2014.

Sukiman. 2012. Pengembangan Sistem Evaluasi. Yogyakarta: Insan Madani

Tan Seng Chee \& Angela F.L Wong (Eds) (2003), Teaching amd learning with technology. An Asia-Pasific Perspective. Singapore Precentice Hall

Virdayana. 2011. Pengembangan Model Pembelajaran Realistic Mathematic Education Pada Mata Pelajaran Mekanik Teknik Bangunan untuk Menungkatkan Efektifitas Hasil dan Proses Belajar http://documents.tips/documents/sk-kd-ips-sddarsono-pgsdpdf.html. 